\title{
Is Decolonization the Answer to Indigenous Under- achievement? Comparing Rhetoric with Reality in New Zealand and Canada
}

\author{
John R. Minnis (University College of the North)
}

\begin{abstract}
The paper compares the rhetoric of decolonization put forth by indigenous scholars with the reality of educational outcomes in New Zealand and Canada and discusses the implications of two common themes emerging from the discourse: (1) cultural determinism in which both First Nations and Maori scholars fundamentally but narrowly depict education as a means to conserve language and cultural heritage -- which results, intentionally or unintentionally, in (2) a hardening of racial/ethnic boundaries. The paper critiques the appropriateness of both themes in the context of the widely accepted notion that indigenous peoples in both countries need to attain higher levels of educational attainment and improve educational performance in order to compete in a knowledge-based, global economy.
\end{abstract}

Résumé: L'article compare la rhétorique de décolonisation avancée par les érudits autochtones avec la réalité des résultats de l'enseignement en NouvelleZélande et au Canada et discute la portée des deux thèmes communs qui émergent des discours: (1) un déterminisme culturel dans lequel les érudits des Premières Nations et du peuple Maori représentent l'éducation de façon fondamentale mais étroite, comme le moyen de préserver l'héritage linguistique et culturel -- dont les résultats volontaires ou involontaires, amènent à (2) un durcissement des frontières raciales ou ethniques. L'article critique la justesse des deux thèmes dans le contexte de la notion généralement acceptée que les peuples autochtones dans ces deux pays ont besoin d'atteindre un niveau d'éducation plus élevé et d'améliorer leurs accomplissements académiques pour pouvoir compéter dans une économie globale et basée sur la connaissance.

Over the last few decades there has been a vast outpouring of scholarly research and writing on indigenous peoples. Scholars and activists alike have made many claims as to the form and capacity of indigenous education to transform the lives of indigenous peoples who feel marginalized and oppressed by neo-colonialism, globalization, and racism (e.g., Champagne, Torjesen \& Steiner, 2005; Spivak, 1999; McConagy, 2000; Durie, 2005). Nowhere are such sentiments expressed more passionately than in New Zealand ${ }^{1}$ and in Canada ${ }^{2}$ by a growing number of indigenous scholars and activists. 
In the context of transforming large segments of society to recognize and include indigenous knowledge and histories, activists argue for the radical transformation of "western" education ranging from early childhood to postgraduate education. Here, the goal is quite specific -- to decolonize education and create conditions to ensure that indigenous people have genuine opportunities to be represented and participate equally in conventional institutions as well as to reconstruct their own identities on their own terms (Schissel \& Wotherspoon, 2003, p. 26).

What is not clear in either country, however, is the degree to which the rhetoric of decolonization is matched by corresponding educational outcomes. An underlying premise of decolonization is that the lack of indigenous knowledge in the school curriculum and the inability of indigenous people to influence the organization of education, are the primary factors in explaining school failure (Binda, 2001).

If decolonization practices are the solution to indigenous underachievement, it is not unreasonable to assume that this would have, by now, resulted in improved academic performance and achievement. However, there is ample statistical evidence indicating that First Nations and Maori populations continue to under-perform relative to their respective "mainstream" populations at virtually all levels of formal education (Battiste, 2000; Bell, 2006; Else, 1997; Vermaeten, Norris \& Buchmeier, 2004).

In an effort to explain the gap between rhetoric and reality, I compare First Nations with Maori educational discourse and find that two interrelated themes dominate. The first is straightforward enough. Indigenization is depicted as a process whereby education must be culturally grounded -- the ultimate purpose of which is to inculcate youth with indigenous languages, values and knowledge. The second theme, which may or may not be an unintended consequence of the first, perceives education as a means to harden racial/ethnic boundaries rather than overcome such. I argue that these themes, to the extent that they are widely endorsed, defined and interpreted as policy, reflect an inwardlooking, atavistic philosophy of education which is essentially counterproductive to overcoming the worst vestiges of neo-colonialism in both nations, i.e., chronic unemployment, institutional racism, and alienation. I argue that Maori and First Nations people within the global economy have an equally important responsibility to focus on strategies and policies aimed at raising the academic standards and educational attainment of indigenous students.

The paper begins with background information on Maori and First Nations peoples followed by an overview of major educational trends and outcomes. A brief synopsis of the indigenous world view is then presented followed by an overview of major educational trends of both groups. The 
Discussion that follows is centred on the implications and ramifications of the two themes alluded to above.

\section{Background}

Indigenous elites and organizations in both Canada and New Zealand have been particularly influential in persuading their respective governments to invest heavily in educational programs and services aimed at increasing participation and achievement. Such programs and policies take many forms, but the common goal is to infuse and/or replace so-called Eurocentric philosophies and instructional methods in mainstream educational institutions with indigenous epistemological perspectives to the extent possible (Rata, 2004; 2005; Charter, 1996).

In an attempt to respond to indigenous concerns, many provincial and territorial governments in Canada have induced schools, universities and community colleges to introduce initiatives aimed at enhancing accessibility and retention. While the financing of aboriginal elementary and secondary education is largely a federal government responsibility, provincial and territorial governments exercise authority over the school curriculum and the certification of teachers. Emphasis has been placed on improving recruitment, counseling, and employment services. In addition, there have been notable changes in school and postsecondary curricula designed to incorporate aboriginal knowledge, culture and languages (Richardson \& Blanchet-Cowan, 2000).

A host of special postsecondary programs including transition and preparatory models have been established in most provinces and regions of the country (Sloane-Seale, Wallace \& Levin, 2000). These programs began in the areas of teacher training and law, and have now expanded to health, science, and business fields.

In order to offset the negative effects of cultural discontinuity and socioeconomic marginalization in New Zealand, a number of alternative educational innovations have emerged over the years. Notable among these has been the establishment of three public tertiary institutions (wananga) to provide programs stressing the application of knowledge regarding ahuatanga Maori (Maori tradition) according to tikanga Maori (Maori custom). Of great importance to the Maori have been the recognition of To reo Maori (Maori language) as the second official language along with English (Lunt, Spoonley, \& Mataira, 2002) and the formation of Waitangi Tribunal in 1975. Both events marked the emergence of New Zealand as a predominantly bi-cultural nation.

The establishment of the Waitangi Tribunal in 1975 and the subsequent extension of its remit in 1985 reaffirmed the provisions in the original 1840 Treaty of Waitangi, long considered the founding document of New Zealand as a nation. The creation of the Tribunal has had the effect of stabilizing Pakeha ${ }^{3}$-Maori relations, elevating it to a position of central arbiter of disputes. Nevertheless, 
debates around citizenship, identity, land and fishing rights that took centre stage in the post-World War II period still continue to influence both indigenous and non-indigenous discourses today (Lunt, Spoonley \& Mataira, 2002).

Despite the outward appearance of ethnic and political harmony, the cultural wars rage on in New Zealand ${ }^{4}$ and the Maori continue to suffer from their status as dependent wards of the state. Modest improvements notwithstanding, they are beset by major disparities in all measurable areas: education, crime, employment, incarceration, morbidity and mortality (Fleras, 1992). Many Maori youth have lost any ability to speak or think in their mother tongue, much less to identify with their cultural heritage. Such circumstances are explained by activists as the result of continued colonization in the classroom (G. H. Smith, 1997; L T. Smith, 1994) and the lack of political power.

The ideology of kauppa Maori education ${ }^{5}$ is perceived as the solution to persistent academic under-performance. Since the 1980s, Maori activists have campaigned for a separate Maori education extending from early childhood education to the university level. Maori scholar, Elizabeth Rata, (2004) observes, however, that there is little evidence to support the claim that kaupapa Maori education produces high achieving students. Rata suggests that because many Maori children are from homes in low socio-economic areas, it is not surprising that these children do poorly in school. Rata argues that having parents who are themselves semi or wholly illiterate, Maori children growing up in this environment are excluded from the "literacy culture of the educationally successful” (p. 12). Thus, according to Rata, blaming the school for its "western", middle-class culture overlooks the fact that, "the literacy culture of the educationally successful, rather than being a middle class possession, is essential to democracy" (p. 12). While Rata acknowledges that while the school environment no doubt plays a part in educational success or failure, its effects provide only a partial explanation. Empirical research conducted by Nash (2006) in New Zealand demonstrates that it is within the family that the principal sources of variance in Maori educational achievement are located.

Indigenous elites cannot hide from Rata's critique. Moreover, it is well known that in developed countries generally, fewer and fewer jobs are open to those who are denied, or reject, formal education; and for the young, long periods in schools and university increasingly appear not as an option, but as a necessity (Wolf, 2002; Hauser, Warren, Huang \& Carter, 2000). The notion that colonization can be overcome by cultural rejuvenation ignores the social and human capital that accrues from the possession of academic credentials and the potential this holds for economic and social development. By not placing a high enough priority on educational achievement, are indigenous elites unwittingly contributing to the further socio-economic marginalization of their own peoples? 
What is the Indigenous World-view?

Readers unfamiliar with indigenous discourse should be aware that no simple definition can be extracted from the burgeoning literature. However, a number of scholars have identified beliefs they feel are central to being an aboriginal in Canada. Hamilton and Sinclair (1991) and Brant (1990) reiterate the cultural imperatives of non-interference, non-competitiveness, sharing, and emotional restraint as among primary principles. Darou (1987) cites the commonly held virtues of cooperation, concreteness, non-interference, respect for elders, and respect for land as an animate entity with spiritual meaning. Charter (1993) and Couture (1987) emphasize understanding, consideration, and equality in human relations. Couture (1987) states, "these values are the roots of a number of characteristic behaviors, the understanding of which must be regarded as essential to educational planning and development” (p. 182).

Armstrong (1987) and Ryan (1995) emphasize the holistic nature of aboriginal learning and how it is part and parcel of daily experience. Each person in turn is both a teacher and student. Knowledge is meant to be shared and conceived as serving collective needs and imperatives. Rheault (2002) echoes the comments of Couture (1996) who stresses the aboriginal need to seek equilibrium between "academic" methods and "traditional" methods in the interest of developing a mutually valuable and culturally non-threatening classroom.

In general, the indigenous world-view takes for granted that human life is inseparable from nature and the supernatural. Living creatures and non-living objects in nature as well as supernatural beings are deemed to be human-like in their motivations, feelings, and interactions. Inanimate objects all possess human traits and can be involved with humans in everyday affairs much the same as other people. Rather than an emotional and intellectual separation between mind and body, the indigenous worldview is a seamless web of humans, nature, and the supernatural. For both Maori and Canadian aboriginals, what binds the community is its "spiritual contract" - its time-honored relationship to the dead, to the living and future generations - links to past generations and to the stories and legends of the elders that connect those links (Lunt, Spoonley \& Mataira, 2002).

From a post-colonial perspective, modernity, rationality, and science are usually dismissed as enemies of the indigenous world view. All forms of western culture are suspect; scientific knowledge in particular is defined as an insidious tool of cultural and economic domination - the handmaiden of capitalism which manifests itself in all levels and processes of formal education (James, 2001). Non-aboriginal teachers and researchers are particularly suspected since their main task is to reproduce the relations of domination which effectively prevents the development of an alternative indigenous scholarly paradigm (Wilson, 2001; Pidgeon \& Hardy Cox, 2002; Rheault, 2002). 
To sum up, indigenization calls for the restoration and infusion of indigenous ecologies, consciousness, and languages into mainstream educational institutions. Maori activist and educator Graham Smith aptly sums up the challenge, "the answers are within us ... what are we going to do about it?" (cited in Battiste, Bell \& Findlay, 2002, p. 85).

\section{Key Educational Trends and Outcomes}

Maori

While the Maori constitute 15\% of the total New Zealand population, they make up $20 \%$ of the total education population. School attendance is compulsory from age 6 to 16; however, it is normal for children to be enrolled in early childhood education well before their fifth birthday. There are now about 4,200 centres offering early childhood education. One of the most successful indigenization initiatives has been Te Kohanga Reo which offers an all day Maori language immersion program to children under five. By 1994, there were over 13,000 children receiving their education predominantly in the Maori language (Crooks, 2002, p. 238), attending programs in over 800 centers representing $50 \%$ of all Maori children enrolled in early childhood education programs.

The stress on early childhood education represents an important outcome given that the Maori population is very young and has a population growth rate many times that of the non-Maori population. In 1998, about 30\% of Maori aged $16-24$ were in some form of education, compared to $47 \%$ of non-Maori. However, Maori participation at this level does not carry over to higher levels (OECD, 2006).

In 2003, only 9\% of Maori students gained a qualification that allowed them to attend university; a significant portion were persistently truant, left school at a young age or left school without a qualification. Maori truancy rates are twice that of non-Maoris with girls slightly more likely to be truant than boys. Age 16 is the minimum school leaving age which means that a large proportion of Maori young adults leave school without the necessary entrance qualifications for postsecondary study and without adequate qualifications for the most basic kinds of employment (McKenzie, 2005).

Generally, Maori have lower levels of educational achievement than nonMaori. While the reasons are complex, 1998 data indicate the following trends (Annual Report on Maori Education, 2004):

-nearly 7,500 Maori gained a tertiary qualification (2,825 men and 4,666 women). -most tertiary qualifications are from polytechnics (65\% - diplomas and certificates), wananga (6\% -- certificates and diplomas), universities (26\% mainly at bachelor's level) and colleges of education (4\%). 
-of all tertiary qualifications earned, $70 \%$ were in diplomas and certificates achieved mainly from wananga (not including advanced diplomas or postgraduate diplomas). Only $4 \%$ were in honors, masters and doctorates degrees.

-Commerce and business was the most popular field of study (15\%) followed by humanities (14\%) and education (8\%).

-More Maori women are graduating than men and Maori graduates tend to be older than their non-Maori counterparts. Roughly $60 \%$ of Maori graduates were aged 25 years and over, compared to $48 \%$ of non-Maori graduates.

-of all the awards completed by Maori $(7,500)$, only 125 were in law, 58 in engineering and 1 in mathematics. However, the number of doctoral programs completed each year by Maori has increased from seven in 1998 to 29 in 2003.

Despite overall increases in educational participation by the Maori, this has concentrated at lower levels of New Zealand's qualifications framework. Maori remain significantly under-represented at degree and post-degree levels and have a higher proportion of students who leave school with low or no qualifications. Maori also tend to be overrepresented in general subjects related to society, culture, and social services. However, Maori students who achieve qualifications do tend to move on to further study - $51 \%$ who completed a qualification in 2002 continued to study towards a further qualification in 2003 and $64 \%$ of wananga students who completed a qualification in 2002 continued to study towards another qualification in 2003. As is the case amongst Canada's First Nations people, Maori women and mature students make up disproportionately high numbers of those at the postsecondary level.

\section{First Nations}

Despite quantitative improvements over the years, educational achievement for First Nations populations continues to be much lower than that of other Canadians. The drop-out before completion of Grade 9 is about $20 \%$ and $40 \%$ before completion of Grade 12 - compared to $3 \%$ and $16 \%$ respectively for the Canadian population (Macionis \& Gerber, 2005, p. 234).

Secondary school completion rates have persistently lagged behind that of mainstream society although there has been some improvement at this level: from a 31\% high school completion rate in 1991 to $37 \%$ in 1996. This compares with a $65 \%$ high school completion rate for Canada as a whole. However, at this rate, it will take about 23 years for First Nations people to reach parity with the Canadian norm (Indian and Northern Affairs Canada, 2000, p. 14).

At the postsecondary level, the number of First Nation citizens attending postsecondary institutions has trebled from 1986 to about 30,000 in 1996 (Hull, 2000). Most of this increase has been absorbed by community colleges that offer one and two year certificates and diplomas. However, First Nations university undergraduate degree completion rates are very low. According to Hampton 
(2000), most students drop out before the second year of study. Fifty-one percent of the First Nations population has less than a high school graduation certificate compared to $31 \%$ for Canadians as a whole.

Only 26\% of First Nations individuals hold a post-secondary credential compared to $45 \%$ of the Canadian working-age population. In 2001, only 5\% of the First Nations population aged 25-44 were university graduates as opposed to $22 \%$ of the total Canadian population. In that same age group, 38\% of the First Nations population had not graduated from high school compared with $18 \%$ in the total Canadian population (Vermaeten, Norris, \& Buchmeier, 2004, pp. 208-209).

The data indicate that large numbers of First Nations students are not acquiring basic academic skills. This is a matter of some concern since the First Nations population is very young; about one-third is under age 14 and has a median age of 25 compared to 35 for all Canadians. The First Nations population as a whole is growing faster than any other group with a birthrate that is estimated to be $70 \%$ higher than non-aboriginal Canadians (Avison, 2004).

According to the most recent Census of Canada (Canadian Statistics Canada, 2003), the proportion of First Nations people with "some postsecondary education" (with or without a certificate, degree, or diploma) is $40 \%$ compared to $55 \%$ for the Canadian population as a whole. In 2001, the proportion of First Nations people with a postsecondary credential was $26 \%$, an increase from $20 \%$ in 1996. These trends indicate increased educational attainment; however, they may also reflect a compositional effect due to the inclusion of a larger population of previously non-registered individuals to the Indian Register (Vermaeten, Norris \& Buchmeir, 2004, p. 209).

\section{Discussion}

Decolonization discourse on education privileges the learning of indigenous values over Eurocentric knowledge, values the process of learning over the learning of subject-matter, eschews academic rigor, standards, and competition, assumes that students are equal to teachers, and rates the development of selfesteem amongst students higher than the need to be literate or aware of other cultures (Charter, 1996; G. H. Smith, 1997; L.T. Smith, 1994).

However, in the knowledge economy, an emphasis on culturally-bound formal education is essentially out of place. Even elementary/secondary education is no longer considered the basic education required to participate in the global labor market. Increasingly, post-secondary education has become the pre-requisite to most jobs being created not only in New Zealand and Canada but throughout the industrial world (OECD, 2006; Ferrer \& Riddel, 2002).

Further, research has shown that since the early 1970s, there have been major changes in the effects of education on earnings in post-industrial societies, 
and these have increased the relative value of high school graduation and postsecondary attendance (Bills, 2004). Schooling has become more important over the generations because levels of educational attainment have themselves increased. Arguably, educational attainment matters more than ever before in history. And not just any education: having the right qualifications, in the right subjects, from the right institutions, is of ever growing importance. Fewer and fewer jobs are open to those who are denied, or reject, formal education; and for the young, long periods in schools and university increasingly appear not as an option, but as a necessity (Wolf, 2002).

Despite these trends, Indigenous elites make no genuine attempts to improve the quality of indigenous education for to do so would risk public condemnation and government calls for greater accountability. Indigenous activists often assert that government under-funds education relative to mainstream education which is then claimed to be a cause of educational underachievement. The claim is frequently made that mainstream teachers are to blame for the high rates of indigenous school failure or that universities are "alien" environments and remain closed to indigenous values (e.g., Kanu, 2005). But do these claims have any empirical support?

First, the claim of "under-funding" is largely a red herring, part of the political struggle between First Nations and the government. In fact, the Canadian government in 2005 spent $\$ 1.2$ billion on First Nations education (K-12) serving 503 schools and only 140,000 students. The cost of postsecondary education, another federal financial responsibility, rises each year totaling \$287 million in 2000 serving about 27,000 students. Expenditures for elementary and secondary education are among the Canadian government's largest allocation to First Nations representing $21 \%$ of total funding toward social programs ("Good Idea for Schools", 2006).

The assertion that "under-funding" is a cause of student failure is also undermined by the fact that since the early 1970s, First Nations political and educational authorities have had the right to train teachers and introduce culturally appropriate curriculum initiatives. While it is true that funding agreements demand that First Nations schools follow provincial curricula and teachers are provincially certified, parents of First Nations students have little idea as to where their children rank relative to non-reserve schools. Lacking such information, there is no assurance either that their child is receiving a quality education that adequately prepares him or her for postsecondary studies (Binda, 2002).

Poor educational outcomes should present a conundrum to activists since their rhetoric calls for an on-going commitment against colonization on the part of the younger generation. Yet it is abundantly clear that First Nations students are not sharing the educational achievements of other Canadian children. Activists and First Nations political authorities are not entirely to blame for this. 
Jurisdictional disputes have created a far from level playing field and a patchwork of delivery systems that have undermined educational quality. While the federal government requires First Nations schools to meet provincial curriculum and teacher certification standards, they receive only $60 \%$ of the funds available to provincial schools (cited in Bell, 2006, p. 3). Moreover, as alluded to above, provincial jurisdictions do not collect comparable performance data; presently, British Columbia is the only Canadian province able to separate aboriginal student data from the general population (Bell, 2006). Operating as separate entities, band schools lack designated money for assessment of achievement and many do not participate in provincial testing programs, preferring a holistic approach to student evaluation (Matthew and Kavanaugh, 1999).

\section{Is Decolonization Rhetoric a Mask for Cultural Determinism?}

Returning to the Maori, Rata (2004) argues that the belief in a separate, culturally unique pedagogy represents a type of cultural fundamentalism - the main premise of which is that one's ethnicity and/or race actually causes the way one thinks and learns. It is assumed that the indigenous child, for instance, inherits his or identity. Thus the task of education is straightforward - to recognize and nurture this identity - "rather than fit the child with dispositions that enable him or her to identify with range of social groups that make up modern societies" (p.9).

In another paper, Rata (2005) suggests that cultural fundamentalism has led to the belief in the sanctity of a unique Maori epistemology which must be faithfully practiced if academic achievement is to improve. Rata suggests that such a one dimensional understanding of learning ignores the important effects of home and social class variables. Maori activists have also downplayed the growing socio-economic disparity between rural and urban Maori populations which tends to undermine activists' claims that the Maori material culture is essentially uniform. Research by Johnston, Poulsen and Forrest (2005) confirm Rata's view. There are indeed substantial variations across urban centres in the degree of residential segregation of those claiming Maori ethnicity. Where they are relatively more numerous, Maori are more likely to be disadvantaged in the lower strata of the labor and housing markets. Where they are relatively less numerous, Maori are more likely to participate in the middle and upper strata of the labor and housing markets.

Despite growing internal socio-economic differentiation amongst Maori populations, activists continue to rhetorically fixate on differences between Maori and Pakehah, claiming that all Maori children will behave in certain pre-defined ways regardless of the social milieu or the actualized family and home culture of the child. As Rata suggests, this view leads to the illogical conclusion that the child will benefit only from knowing about the Maori culture. 
In Canada, similar, culturally deterministic sentiments are strongly evident in the discourse on "aboriginal learning styles" ${ }^{6}$, cognitive structures which are thought to originate in one's genetic makeup. Many researchers have argued for some time that indigenous children bring with them into the classroom their own "learning style". Traditional culture and traditional child-rearing customs are thought to be influential in the development of a culturally determined "learning style" (Kaulback, 1984). Browne (1990) suggests that indigenous students are "right-brain” learners. Scaldwell, Frame and Cookson (1984) argue that aboriginal students prefer to learn through observation and the manipulation of real examples.

The implication for aboriginals is that if an aboriginal student has succeeded in mainstream education, one either never thought like an aboriginal or has been indoctrinated by the educational system into no longer thinking like an aboriginal. Even if there was a grain of truth to the "right-brained", "left-brain" thesis, to use it as a way to understand complex people and complex problems is highly questionable. Despite doubts about the scientific credibility of such views, the idea of a pedagogy rooted in genetics/race/culture is still quite popular amongst aboriginal activists as expressed in the influential policy document, Royal Commission on Aboriginal Peoples in 1996 (cited in Battiste, et al. (2004) :

The destiny of a people is intricately bound to the way its children are educated. Education is the transmission of cultural DNA from one generation to the next. It shapes the language and pathways of thinking, the contours of character and values... (p. 82).

Returning to New Zealand, Rata spells out the implications of such thinking applicable to Maori ideology, i.e., if education is to be predicated on one's genetic endowment, then one's race/ethnicity should be recognized as a separate political category. How else to ensure that one's distinctive identity is protected? In order to preserve this distinctive identity, a narrowly-focused definition of education and a separate educational system obviously constitute an ideal fit. And yet, as Rata suggests, any cultural or ideologically-bound pedagogy can easily narrow students' horizons and turn them into prisoners of their own culture. Taking Rata's argument one step farther, it can be argued that a culturally-determined curriculum may have the unintended consequence of depriving students of the necessary intellectual tools and academic credential required in the struggle against colonization.

Despite Maori activist claims to the contrary, the relationship between tribal and other Maori identities is highly contested. The Maori Congress, a tribally-based national body set up in 1990 has been struggling since its inception to reconcile a desire for greater tribal self-determination with the desire for a stronger collective Maori voice that transcends tribalism (Durie, 1998). Contrary to such rhetoric, the creation of formal structures that acknowledge both 
sentiments within a single Maori nation has yet to be achieved. Demographic realities and socio-economic disparities conspire to prevent the development of a collective, uniform Maori voice.

Urban Maoris, for example, often view their plight differently from their rural counterparts because the latter tend to reside in segregated neighborhoods, suffer from higher unemployment, and experience lower educational attainment levels. Intermarriage between urban Maori and Pakehah is quite high, with some $42 \%$ intermarrying - while the rate for rural Maori is only $15 \%$, according to one study (Callister, 2003).

In Canada, First Nations people are experiencing dramatic demographic changes that undermine notions of cultural homogeneity and thus raise questions about the viability of a culturally-inclusive philosophy of education. First Nations people are both an urban and rural people with approximately $40 \%$ living offreserve, mainly in cities and towns (Guimond, 2003). They also demonstrate a high inter-marriage rate with non-aboriginals estimated at 34\% for on-reserve people and 62\% for off-reserve people (Clatworthy \& Smith, 1992). The shift from rural to urban areas on the part of both groups reflects a high level of cultural exchange and interaction.

Demographic trends weaken activist claims that in both countries that there are ineffable differences between indigenous and mainstream peoples. It appears that indigenous societies are increasingly penetrated societies. Their members live in many worlds at once and relate to more than one community (Cairns, 2000). Arguably, human freedom expands with compartmentalization of roles and the expansion of social circles. The more groups a person identifies with, the more freedom he/she has because constraints are lessened and greater opportunities for social interaction emerge. Expanding one's circle of acquaintances and friends liberates individuals from the constraints of external institutions, such as the State, church, and economic groups. Similarly, expanding one's stock of knowledge and skills beyond what is culturally sanctioned can empower indigenous people by increasing their choices and allowing them to partake of multiple statuses and roles.

Because both Maori and First Nations people enjoy freedom of mobility and the ability to claim multiple identities, indigenous cultures cannot be assumed to be static and immune from intense acculturation and assimilation forces. In New Zealand, Chapple (2000) drew attention to government policy in this regard. He noted that government calculations as to Maori identity included many children with non-Maori parents who, for political purposes, were placed in the Maori census category when they should have been placed in the "mixed" category. The reality of mixed ethnicity is largely accepted by indigenous peoples in both countries. However, governments continue to emphasize ethnic difference 
in government policies. This seems confused at best and ideologically blind at worst in both nations.

\section{Will Decolonization Harden Ethnic/Racial Boundaries?}

In New Zealand, Rata (2004) claims that the ideology of Kaupapa Maori, which celebrates the uniqueness and centrality of Maori culture does so at the expense of hardening ethnic boundaries and social divisions that are originally claimed as the justification for decolonization. Rata further argues that Kaupapa Maori ideology assumes that genetic/race/kinship groups are foundational and primordial and that a person's primary identity is as a member of the ancestral race or tribal group and that tribal identification will result in increased self-esteem. The third assumption is that the culture of the race-group is caused by the genetic composition and is therefore exclusive to the ancestral group of that race (Rata, 2004, p. 3).

Are Rata's concerns relevant to Canada? Research by White, Maxim and Spence (2004) suggest that class cleavages between indigenous elites and the mass of First Nations people are growing on reserves due mainly to the nature of reserve politics and the way in which financial transfers from the federal government to First Nations are distributed. First Nations political leaders, who manage finances and decide on their distribution, have emerged as an elite group who enjoy wide financial and political powers that affect the everyday lives of First Nations members.

Another critic of First Nations political organization, Gene Allard (2002), supports the above claim. Allard demonstrates how the increasing level of social stratification on First Nations reserves leads to increasing social-economic polarization between the "haves" and the "have-nots". The "haves" and "havenots" are differentiated not only by kin and family but by educational attainment levels that results in a dual labor market on reserves. Individuals are either limited to low-skill, low-paying jobs, or high-skill, high-paying jobs in the First Nations bureaucracy. Allard further suggests that in the absence of taxation and because traditional customs of sharing and redistribution are no longer practiced on many reserves, there are few legal or normative mechanisms for redistributing wealth from the elite to the "rest".

Notwithstanding Allard's argument, this is not to suggest that First Nations people employed on reserves should be taxed. However, the lack of taxation removes an important variable from the democratic political process, that is, there is no legitimate basis for band members to demand accountability from elected officials as there is, in contrast, to mainstream society. The implication is that individual band members are relatively powerless to influence educational policy through the ballot box, which in turn, strengthens the hand of elites who benefit from the centralized nature of political decision-making. Carstens (2000) points out that there are few mechanisms within the reserve political system that 
allows for grassroots involvement or wholesale resistance to political decisions. Real power and authority under the Indian $\mathrm{Act}^{7}$ are vested in political offices, and whoever gets into office enjoys a wide range of discretionary powers not unlike that found in authoritarian states.

Because the better paying jobs require post-high school training, there is keen competition for educational sponsorships and funding. Given their control over funding and jobs, First Nations political leaders are left unimpeded to exploit individuals who are in competition with one another for such funding.

These conditions unique to Canada's reserve system do not exist in New Zealand and because there is considerably more cultural heterogeneity amongst Canada's First Nations than amongst the Maori, it would be unfair to assume that indigenous education in Canada is a covert attempt at hardening ethnic/racial boundaries.

Wither Educational Standards and Educational Attainment?

The global economy demands ever-higher levels of formal education for employment. The strong correlation between educational attainment and employment, economic well-being, and health has been well established (Bills, 2004).

Ironically, indigenous activists, most of whom are university educated themselves, fail to extend the very same privileges and opportunities taken advantage of by them to others. The indigenous discourse is silent on the economic value of educational credentials, and how credentials alone reflect social and human capital far beyond the content embedded in, for example, a university degree program. Attaining a university degree plays two different roles in the labor market. The first is to distinguish those with credentials from those without. The second is to "open the door" to further education since entrance to a higher level is normally contingent on successful completion of the lower level. Obtaining the credential, whether in the form of licensure, professional certification, or academic degrees, is the outcome which pays off the most.

In Canada, indigenous activists and academics have largely ignored the reasons for particular patterns of under-achievement. They have uncritically assumed that "cultural discontinuity" and "decolonization" (see Schissel \& Wotherspoon, 2003) are the root causes of school failure when in fact neither theory has been empirically verified. Nor does either theory explain why so many First Nations people leave their home reserves and migrate to the cities and, over the course of many years, discover that their children tend to academically outperform on-reserve aboriginals. And yet, in urban areas, the curricula, pedagogical methods, and school environment are not predicated on aboriginal culture (Schissel \& Wotherspoon, 2003). Clearly, exposure to "western” pedagogy and the attainment of university degrees has allowed the indigenous elite to hold 
respectable and well-paying positions in academe, government, and business. Why they should not advocate the same for their own people is perplexing when there is ample evidence indicating what the benefits are.

The accrued benefits of high educational attainment are well documented and significant to any First Nation band wishing to weigh the costs/benefits of decolonizing the curriculum as against taking steps to improve attainment levels. Research shows that educational attainment is clearly a primary determinant of many First Nations' community outcomes, including economic development, population health, and welfare (White, Maxim \& Spence, 2004).

Ironically, Canadian activists also forget to mention that First Nations people presently enjoy a very high rate of return to education (George \& Kuhn, 1994; Patrinos \& Sakellariu, 1992; Jankowski \& Moazzami, 1995). These studies indicate that there is a return to education of about $7.8 \%$ for each year of elementary and secondary education completed and $31 \%$ for university training.

Another study indicating the benefits to be had from post-secondary education is that of Eric Howe (2004). His study in Saskatchewan demonstrated the added value of educational achievement for First Nations people. Howe calculated that lifelong income disparities between First Nations and nonaboriginals tend to disappear as educational attainment rises for First Nations people. In fact, First Nations people receive a "double benefit" from education. Moreover, First Nations women receive a "triple benefit": their earnings rise because average earnings rise with education, because their incomes are catching up with men, and because their incomes are catching up with non-First Nations people. Howe summarizes his findings accordingly:

Income foregone to an individual represents a loss to society both in terms of what the individual would have produced to earn that income, and also any resulting expenditure on social assistance programs. The half million dollars a young aboriginal man wastes by dropping out of high school is a loss to him, but is also a loss to society. When a young aboriginal woman drops out of school, society's loss of the value she would have produced is great, but probably less than the resulting social assistance payments. It would be better to have programs that would keep both of them in school \{italics mine \} (p.189).

In addition to the "premium" associated with educational attainment, there is the matter of "sheepskin" effects ${ }^{8}$ associated with the completion of university degrees. Relative to high school completion in Canada, a bachelor's degree raises earnings by as much as $26 \%$ for men and $29 \%$ for women. According to one recent study, the average annual income of a university graduate in 2001 was $\$ 61,823$. That was $\$ 25,545$, or fully $70 \%$, more than a person with a high school diploma (Mintz, 2004, p. 3). There are also large variations in lifetime earnings relative to what is studied; however, bachelor's degrees are the 
credentials that produce the highest returns in all fields (Ferrer \& Riddel, 2002). The largest sheepskin effects $-35 \%$ or more for males and females - are for professional programs in medicine, dentistry, veterinary medicine and optometry. Additional degrees beyond the bachelor's level have small or insignificant effects on earnings in all fields of study. These statistics show that there are clear advantages to be had for First Nations people provided they complete their studies.

\section{Concluding Comments}

In an attempt to recapture the past and reclaim what they believe is their rightful place in society, indigenous elites in New Zealand and Canada have taken the initiative in demanding a radical restructuring of formal education to include their respective world views. So far, efforts aimed at achieving this goal have not resulted in the improvement of educational outcomes.

However, decolonization rhetoric aimed at restructuring the mainstream educational system has resulted in culturally-deterministic, politically motivated approach to education in which "culture" trumps all else. In light of the questionable ability of indigenous education defined this way to improve the life chances of indigenous peoples, indigenous elites and activists may wish to rethink their obsession with culture. What is to be gained by dwelling incessantly on the connection to one's culturally different origins as a means to overcome colonization if this continues to result in educational under-achievement that not only fuels the sense of separateness between indigenous and mainstream populations, but also widens the socio-economic gap?

While there is a recurring emphasis on "cultural retention" and "cultural preservation" in Maori and First Nation discourse, there is little or no corresponding emphasis on the need to build and protect a distinctly Canadian or New Zealand nation state. Maori and First Nation discourse tends to erode the claim to common truth by maintaining that ideas should be assessed according to the race/ethnicity of those who present them. I am left to conclude that neither group has a sense of a common humanity, only a "First Nations" or "Maori worldview." 


\section{Notes:}

1 The indigenous Maori constitute about 15\% (585,900 people) of New Zealand's population of 3,900,000. The rest of the population is of European origin (75\%); Pacific Islanders (6\%); and Asians (4\%) (Crooks, 2002). The Maori consist of a number of tribes (iwi) having occupied what is now New Zealand for up to a thousand years prior to European contact in the $18^{\text {th }}$ century. In 2021, the number of Maori is expected to reach 749,300 or $16.5 \%$ of the population (Annual Report on Maori Education, 2004).

2 In Canada, the term "aboriginal" is used to refer to three groups: Metis (mixed-race); Inuit, and Indian that together make up roughly 3\% (1.1 million) of the total population (36 million) in 2001 (Avison, 2004). The paper is concerned only with "First Nations" or Indian people $(760,000)$ who, along with the Inuit, are considered "indigenous" to Canada. Most First Nations people are legally referred to as "registered" or "status" persons -- many of whom live on reservations (established by treaty or by government fiat). Registered or status First Nations people are governed by the Indian Act (1876) and are thus the administrative and fiscal responsibility of the federal government. However, over time, First Nations have come to exercise considerable autonomy in administering their own affairs (Armitage, 1995; Frideres \& Gadacz, 2001).

${ }^{3}$ Pakehah is the Maori word for non-Maori people, usually referring to persons of European descent.

${ }^{4}$ Comprehensive historical accounts of Pakeha-Maori relations are provided by McDonald (2001), Barkan (2000), Robinson (2002), and Sharp (1990). Alves (1999) and Brookfield (1999) document in detail the Maori struggle for racial equality and restoration of their lands leading up to the Maori protests in the 1960s, a struggle that effectively shattered any semblance of inter-ethnic harmony.

5 Defined by Elizabeth Rata (2004) as, "the intellectual expression of a neo-traditionalist ideology that serves the class interests of the neo-tribal capitalist elite” (p. 2). See E. Rata (2000) for a comprehensive political economic analysis of the rise and influence of the Maori neo-tribal elite.

${ }^{6}$ In a major assessment of 13 of the most influential learning styles, Coffield (2004) found that none had been adequately validated through independent research; the idea of a learning cycle, the consistency of -visual, auditory and kinaesthetic preferences and the value of matching teaching and learning styles were all "highly questionable". Research on minority students does not yield results that are significantly different from that found in non-minority students.

${ }^{7}$ Created in 1876, the Indian Act and its subsequent amendments provide for the election of a chief and band council for every reserve and/or First Nation. The band's responsibility is to govern efficiently and ensure that the welfare of band members takes priority. However, well over half of the budget allocated to First Nations by the Federal government consists of fiscal transfers and is controlled by band councils with little or no oversight or input from band members (Flanagan, 2000).

${ }^{8}$ Park (1999) defines sheepskin effects as, “disproportionately large increases in returns to schooling after the completion of certain number of years that usually entail a degree” (p. 238). In other words, one is rewarded simply for possessing a degree, or, one is economically penalized for not holding a degree. The difference in earnings between one who has a four year BA and one who hasn't is in effect the "rent" one collects for being credentialed. 


\section{References}

Allard, J. (2002). Big Bear's treaty: The road to freedom. Inroads, 11, 108-169. Annual report on Maori education (2004). New Zealand Ministry of Education.

Armitage, A. (1995). Comparing the social policy of aboriginal assimilation: Australia, Canada, and New Zealand. Vancouver: University of British Columbia Press.

Armstrong, J. C. (1987). Traditional indigenous education: A natural process. Canadian Journal of Native Education, 14, (3), 14-19.

Alves, D. (1999). The Maori and the crown: An indigenous people's struggle for selfdetermination. London: Greenwood Press.

Avison, D. (2004). A challenge worth meeting: Opportunities for improving Aboriginal education outcomes. Report prepared for the Council of Ministers of Education, Canada.

Barkan, E. (2000). The guilt of nations: Restitution and negotiating historical injustices.New York: Norton.

Battiste, M., Bell, L. \& Findlay, L. M. (2002). Decolonizing education in Canadian universities: An interdisciplinary, international, indigenous research report. The Canadian Journal of Native Education, 26, (2), 82-95.

Bell, D. (2006). Aboriginal education in Canada. Education Analyst. Retrieved July 18, 2006 from: www. saee.ca/analyst/C_019.3 HHH_LON.php

Bills, D. B. (2004). The sociology of work and education. Malden, MA. Blackwell.

Binda, K. P. (2001). Aboriginal education in comparative and global perspectives: What has research and practice done for Aboriginal education in Canada? Canadian and International Education, 30, (1), 1-16.

Brant, C. C. (1990). Native ethics and rules of behavior. Canadian Journal of Psychiatry, 35, 534-539.

Brookfield, F. M. (1999). Waitangi \& indigenous rights: Revolution, law \& legitimation .Auckland: Auckland University Press.

Browne, D. (1990). Learning styles and Native Americans. Canadian Journal of Native Education, 17, (1), 23-35.

Cairns, A. (2000). Citizens plus: Aboriginal peoples and the Canadian state. Vancouver: University of British Columbia Press.

Callister, P. (2003). Ethnic measures, intermarriage and social policy: Retrieved May 16, 2006 from: www. msd.govt.nz/keyinitiatives/conference.

Canadian Statistics Canada (2003). 2002 census. Ottawa: Minister of Industry.

Carstens, P. (2000). An essay on suicide and disease in Canadian Indian reserves: Bringing Durkheim back in. The Canadian Journal of Native Studies, 20, (2), 309-345.

Champagne, D., Torjesen, K., \& Steiner, S. (2005) (Eds.), Indigenous people and the modern state. Walnut Creek, CA: AltaMira Press.

Chappel, S. (2000). Maori socio-economic disparity. Political Science, 52, (2), 101-115.

Charter, A. (1996). Integrating aboriginal teaching and learning approaches in postsecondary settings. Issues in the North, 1, 55-64

Clatworthy, S. \& Smith, A. H. (1992). Population implications of the 1985 Amendments to the Indian Act. Ottawa: Assembly of First Nations.

Coffield, F. (2004). Learning styles and pedagogy in post-16 learning: A systematic and critical review. London: Learning and Skills Research Centre.

Couture, J. E. (1987). What is fundamental to Native education? Some thoughts on the relationship between thinking, feeling, and learning. In L. L. Stewing \& S. J. H.

40 Canadian and International Education Vol. 37 no 1 - June 2008 
McCann (Eds.), Contemporary and educational issues: The Canadian mosaic (pp. 178-191). Mississauga, ON: Copps, Clark \& Pitman.

Couture, J. E. (1996). Native studies and the academy. In G. Dei, B. Hall \& D. R. Rosenberg (Eds.), Indigenous knowledge in global context: Multiple readings of our world (pp. 1-14). Toronto: University of Toronto Press.

Crooks, T. J. (2002). Educational assessment in New Zealand schools. Assessment in Education, 9, (2), 237-253.

Darou, W. G. (1987). Counselling and the northern Native. Canadian Journal of Counselling, 21, (1), 33-41.

Durie, M. (1998). Te Mana, Te Kawantanga: The politics of Maori self-determination. Auckland: Oxford University Press.

Durie, M. (2005). Nga tai matatu: Tides of Maori endurance. Melbourne: Oxford University Press.

Else, A. (1997). Maori participation \& performance in education: A literature review and research programme. Report for the New Zealand Ministry of Education.

Ferrer, A. M. \& Riddell, W. C. (2002). The role of credentials in the Canadian labour market. Paper presented at the Canadian Institute for Advanced Research,Vancouver, B.C., June, 2001.

Flanagan, T. (2000). First Nations? Second thoughts. Montreal: McGill-Queen's University Press.

Fleras, A. (1992). The nations within: Aboriginal-state relations in Canada, the United States, and New Zealand. Toronto: Oxford University Press.

Frideres, J. S. \& Gadacz, R. R. (2001). Aboriginal peoples in Canada: Contemporary conflicts ( $6^{\text {th }}$ ed.). Toronto: Prentice Hall.

George, P. \& Kuhn, P. (1994). The size and structure of Native-White wage differentials in Canada. Canadian Journal of Economics, 27, (1), 20-42.

Good idea for schools (2006, March 4). Winnipeg Free Press, p. A14.

Guimond, E. (2003). Changing ethnicity: The concept of ethnic drifters. In J. P. White, P. S. Maxim \& D. Beavon (Eds.), Aboriginal conditions: Research as a foundation for social policy (pp. 91-107). Vancouver: University of British Columbia Press.

Hamilton, A. C. \& Sinclair, C. M. (1991). The report of the Aboriginal justice inquiry of Manitoba (vol. 1). Winnipeg: Queen's Printer.

Hampton, E. (2000). First Nations controlled universities in Canada. In M. B. Castellano, L. Davis \& L. Lahache (Eds.), Aboriginal education: Fulfilling the promise (pp. 208-221). Vancouver: University of British Columbia Press.

Hauser, R. M. \& Warren, J. R., Huang, M-H., \& Carter, W. Y. (2000). Occupational status, education, and social mobility in the meritocracy. In K. Arrow, S. Bowles, \& S. Durlauf (Eds.), Meritocracy and economic inequality (chap. 8). Princeton: Princeton University Press.

Howe, E. (2004). Education and lifetime income for aboriginal people in Saskatchewan. In J. P. White, P. Maxim \& D. Beavon (Eds.), Aboriginal policy research: Setting the agenda for change (pp. 175-191). Toronto: Thompson.

Hull, J. (2000). Aboriginal post-secondary education and outcomes in Canada, 1996. Ottawa: Research and Analysis Directorate, Indian and Northern Affairs Canada.

Indian and Northern Affairs Canada (April, 2000). Report of the Auditor General of Canada. Ottawa: Government of Canada.

Jankowski, W. \& Moazzami, B. (1995). Returns of education among Northwestern Ontario’s Native people. Canadian Journal of Native Studies, 15, (1), 24-30. 
James, K. (2001) (Ed.). Science and Native American communities: Legacies of pain visions of promise. Lincoln, NB: University of Nebraska Press.

Johnston, R., Poulsen, M. \& Forrest, J. (2005). Ethnic residential segregation across an urban system: The Maori in New Zealand, 1991-2001. The Professional Geographer, 57, (1), 115-129.

Kaulback, B. (1984). Styles of learning among Native children: A review of the research. Canadian Journal of Native Education, 11, (3), 27-37.

Kanu, Y. (2005). Teachers' perceptions of the integration of Aboriginal culture into the high school curriculum. The Alberta Journal of Educational Research, 51, (1), 50-68.

Lunt, N., Spoonley, P. \& Mataira, P. (2002). Past and present: Reflections on citizenship within New Zealand. Social Policy and Administration, 36, (4), 346-362.

Macionis, J. J. \& Gerber, L. M. (2005) (Eds.), Sociology: $5^{\text {th }}$ Canadian edition. Toronto: Pearson.

Matthew, N. \& Kavanaugh, B. (1999). Meeting our expectations: Considering a framework for the assessment of First Nations schools. Ottawa: Report of the Auditor General of Canada, Section 4.1.

McConagy, C. (2000). Rethinking indigenous education: Culturalism, colonialism, and the politics of knowing. Oxford: Oxford University Press.

McDonald, R. (2001). The fifth wind: New Zealand and the legacy of a turbulent past. Auckland: Hodder \& Stoughton.

McKenzie, D. F. (2005). Reducing attrition rates for Maori students. Journal of Development Education, 28, (3), 12-19.

Mintz, J. M. (2004). Canada's future in the balance: New approaches to effective education. Paper presented to the Economic Club of Toronto, June 28.

Nash, R. (2006). Challenging ethnic explanations for educational failure. In E. Rata \& R. Openshaw (2006) (Eds.). Public policy and ethnicity: The politics of ethnic boundary making (pp. 156-169). New York: Palgrave Macmillan.

OECD (2006). Thematic review of tertiary education : New Zealand country background report. Auckland: New Zealand Ministry of Education.

Park, J. H. (1999). Estimation of sheepskin effects using the old and new measures of educational attainment in the current population survey. Economic Letters, 62, 237-240.

Patrinos, H. A. \& Sakellariou, C. N. (1992). North American Indians in the Canadian labour market: A decomposition of wage differentials. Economics of Education Review, 11, (3), 257-266.

Pidgeon, M. \& Hardy Cox, D. G. (2002). Researching with aboriginal peoples: Practices and principles. Canadian Journal of Native Education, 26, (2), 96-106.

Rata, E. (2000). A political economy of neotribal capitalism. Oxford: Lexington Books.

Rata, E. (2004). Under-achievement in Maori education: Why Kaupapa Maori can't help. Paper presented at the Politics of Early Childhood Symposium, 21-22 September. Retrieved May 15, 2006, from: www.education.auckland.ca.nz

Rata, E. (2005). The rise and rise of the neotribal elite. Address to the Summer Sounds Symposium, 11-13 February. Retrieved May 15, 2006 from: www.education.auckland.ac.nz

Rheault, D. (2002). A discussion of major tenets and assumptions of Anishinaabe philosophy and aboriginal educational methodology concepts. Retrieved May 11, 2006 from: www. sky-lynx.com/article/ed_method.htm 
Richardson, C. \& Blanchet-Cohen, N. (2000). Postsecondary education programs for Aboriginal peoples: Achievement and issues. Canadian Journal of Native Education, 24, (2), 169-184.

Robinson, G. M. (2002). Treaty and tribunal: Redressing longstanding grievances in Aotearoa/New Zealand. The Round Table, 367, 613-624.

Ryan, J. (1995). Experiencing urban schooling: The adjustment of Native students to The extracurricular demands of a post-secondary education program. Canadian Journal of Native Education, 15, (2), 211-230.

Scaldwell, W.A., Frame, J.E., \& Cookson, D.G. (1984). Individual intellectual asessment of Chippewa, Muncey and Oneida children using the WISC-R. Paper presented at the MOKAKIT conference, University of Western Ontario.

Schissel, B. \& Wotherspoon, T. (2003). The legacy of school for aboriginal people: Education, oppression, and emancipation. Don Mills, ON: Oxford University Press.

Sharp, A. (1990). Justice and the Maori: Maori claims in New Zealand political argument in the 1980s. Auckland: Oxford University Press.

Sloane-Seale, A., Wallace, L., \& Levin, B. (2000). Educational achievement and labor market outcomes of students in the University of Manitoba Access program. Canadian Journal of Native Education, 20, (2), 347-370.

Smith, G. H. (1997). The development of Kaupapa Maori: Theory and praxis. Unpublished Doctoral Thesis. Auckland: University of Auckland.

Smith, L. T. (1994). Decolonizing methodologies: Research and indigenous peoples. Dunedin, NZ: University of Otago Press.

Spivak, G. C. (1999). A critique of postcolonial reason: Toward a history of the vanishing present. Cambridge, MA: Harvard University Press.

Vermaeten, A., Norris, M. J. \& Buchmeier, M. (2004). Educational outcomes of students funded by the Department of Indian and Northern Affairs Canada: Illustration of a longitudinal assessment with potential application to policy research. In J. P. White, P. Maxim \& D. Beavon (Eds.), Aboriginal policy research: Setting the agenda for change (pp. 207-232). Toronto: Thompson.

White, J., Maxim, P. \& Spence, N. D. (2004). An examination of educational success. In J. P. White, P. Maxim \& D. Beavon (Eds.), Aboriginal policy research: Setting the agenda for change (pp. 129-148). Toronto: Thompson.

Wilson, S. (2001). Progressing toward an indigenous research paradigm in Canada and Australia. Canadian Journal of Native Education, 25, (2), 175-179.

Wolf, A. (2002). Does education matter? Myths about education and economic growth. London, UK: Penguin.

John R. Minnis is Associate Professor, Sociology \& Education, University College of the North Box 3000, The Pas, MB R9A 1R2.

He can be reached at: jminnis@ucn.ca 